\title{
Social Determinants Effect on Maternal Mortality in Central Sulawesi Province
}

\author{
Ketut Suarayasa $^{1}$, Hermiyanty ${ }^{2}$, Bertin Ayu Wandira ${ }^{2}$, Muh Rizki Ashari ${ }^{2,}{ }^{\text {* }}$, Pitriani $^{3}$ \\ ${ }^{1}$ Medical Education Unit, Medical Faculty, Tadulako University, Palu City, Indonesia \\ ${ }^{2}$ Departement of Health Administration and Policy, Faculty of Public Health, Tadulako University, Palu City, Indonesia \\ ${ }^{3}$ Departement of Environmental Health, Faculty of Public Health, Tadulako University, Palu City, Indonesia
}

Email address:

Aiiyrizki@yahoo.com (M. R. Ashari)

${ }^{*}$ Corresponding author

\section{To cite this article:}

Ketut Suarayasa, Hermiyanty, Bertin Ayu Wandira, Muh Rizki Ashari, Pitriani. Social Determinants Effect on Maternal Mortality in Central Sulawesi Province. Central African Journal of Public Health. Vol. 6, No. 2, 2020, pp. 62-65. doi: 10.11648/j.cajph.20200602.12

Received: MM DD, 2020; Accepted: MM DD, 2020; Published: February 18, 2020

\begin{abstract}
Central Sulawesi has an area of $61,841 \mathrm{~km}^{2}$. Geographical conditions contribute to delays in receiving health care services. All cultures, education levels, and other social determinants that affect pregnant women who receive ANC. ANC visit data in Central Sulawesi figures show $88.8 \%$ to $78.4 \%$ for K1 and K4. This study uses a case control study design to address the magnitude of risk factors associated with maternal mortality. This research was conducted in the city of Palu and Parigi Moutong district. Social Determinants of Health have a risk of 3,776 times increasing maternal mortality $(\mathrm{OR}=3,776)$ and is a significant factor in maternal mortality in Central Sulawesi $(1,579-9,301)^{3}$ Late acts as a risk factor for maternal death in Central Sulawesi, namely: 1 Late risk 1,680 times increases maternal mortality $(\mathrm{OR}=1,680)$ but is not a significant factor in maternal mortality in Central Sulawesi (0.553-5,100); Being late 2 has a risk of 2,038 times increasing maternal mortality (OR $=2,038$ ) but is not a significant factor in maternal mortality in Central Sulawesi (0.820-5.064); and being Late 3 at a risk of 6,500 times increasing maternal mortality $(\mathrm{OR}=6,500)$, it is a significant factor in maternal mortality in Central Sulawesi $(2,342-18,044)$.
\end{abstract}

Keywords: Social Determinants, Maternal Mortality Rate, Health Care Services

\section{Introduction}

According to Amiruddin (2014), there are 3 (three) causes of a significant reduction in maternal mortality: 1) Facilities and infrastructure that are inadequate or not functioning well; 2) HR related to maternal services has not been evenly distributed, competencies have not been as expected, and cooperation between HRs has not gone well; 3) Unequal access, the referral system between primary services to hospitals has not been running well, or the referral system with Basic Neonatal Emergency Obstetric Services and Comprehensive Emergency Neonatal Obstetric Services has not been running well. [1,2]

Maternal mortality in the context described by Maine (1994) looks more at social determinants of health. This is in line with the topic currently being developed and directed by WHO in an effort to reduce maternal mortality rates, where factors related to culture, education level, poverty, gender equality, become important studies in an effort to uncover the failure of various programs that have so far been implemented. Obstetric complications occur more due to the socio-cultural complexity and poverty of the community so that pregnant women are powerless to access quality health services. Likewise, health status, reproductive status, access to health services and health service utilization behavior, are not able to be maximally achieved due to cultural conflicts, poverty and social status in the family and community which are an important part of the Social Determinant of Health. [3]

To meet the SDG target, countries with an MMR below 432 deaths per 100000 livebirths in 2015 will need to achieve an annual continuous rate of reduction of $7 \cdot 5 \%$ for 2016-30, which is beyond the rate of $5 \cdot 5 \%$ that was required to meet MDGs. Ten countries (Belarus, Cambodia, Estonia, Kazakhstan, Lebanon, Mongolia, Poland, Rwanda, TimorLeste, Turkey) had point estimates greater than $7 \cdot 5 \%$ in 
2000-10. For 30 countries with MMRs greater than 432 deaths per 100000 livebirths in 2015, even higher annual continuous rates of reduction are needed to reduce the MMR to less than 140 deaths per 100000 livebirths in 2030. [3]

Likewise, Central Sulawesi has the largest area in Sulawesi $\left(61,841 \mathrm{~km}^{2}\right)$ or half of the whole island of Java $\left(128,297 \mathrm{~km}^{2}\right)$ [3]. This geographical condition can contribute to delays in receiving health care services. Diverse number of ethnicities (19 ethnicities) and other immigrant ethnicities, cultural diversity of each ethnic group, level of education, and other social determinants that influence the behavior of pregnant women receiving ANC. ANC visit data in Central Sulawesi figures show $88.8 \%$ to $78.4 \%$ for $\mathrm{K} 1$ and K4 [4].

These data indicate that the high and low coverage of antenatal care (ANC) coverage and delivery by trained health workers do not positively correlate with maternal mortality rates. There are several analyzes that can be done on the gap between the ANC coverage numbers and the MMR. First, from the aspect of health workers (midwives) includes midwives' compliance in conducting ANC service standards (10T). With a good ANC and according to standards, can detect early in the high risk of pregnancy so that labor can be planned and delays can be avoided. Second, from the aspect of the availability of infrastructure and the readiness of health facilities in providing quality health services. Third, from the aspect of pregnant women and families in complying with the advice of health workers (midwives). This relates to social determinants such as education, employment, income, family support, and others

This study aims to analyze the effects of social determinants (Education, Employment, involvement in decision making) and assess the risk of three delays in maternal mortality in Central Sulawesi.

\section{Method}

This study uses a case control study design to address the magnitude of risk factors associated with maternal mortality. This research was conducted in the city of Palu (representation of urban areas) and Parigi Moutong district (representation of district areas). The population in this study consisted of case populations and control populations. For the case population, all mothers who died in the Palu City and Parigi Moutong district in the last 2 years (2016 October 2017) were recorded in the data of maternal mortality in the Palu City and Parigi Moutong District Health Office. The sample in this study were all mothers who died in the city of Palu and Parigi Moutong district in the last 2 years (2016 - 2017) which were recorded in the data of maternal deaths in the City Health Office Palu and Parimo district (case sample). Whereas the control sample was all postpartum mothers who did not experience death in the last 2 years (2016-2017), with a case: control ratio $=1$ : 2 .

Data is collected through interviews with questionnaire. Secondary data were obtained through maternal mortality records, $\mathrm{MCH}$ books, cohort registers of pregnant women, labor records and verbal autopsy documentation. Data processing is performed by cleaning (data cleaning before processing), editing (checking data completeness), coding (to facilitate data processing), and data entry (entering data into a computer program for analysis).

\section{Results}

Table 1. Characteristics of Respondents based on Social Determinants in Central Sulawesi Province.

\begin{tabular}{lllllll}
\hline Characteristics of & Case & \multicolumn{2}{l}{ Control } & Total \\
\cline { 2 - 7 } Respondents & $\mathbf{n}$ & $\mathbf{\%}$ & $\mathbf{n}$ & $\mathbf{\%}$ & $\mathbf{n}$ & $\mathbf{\%}$ \\
\hline Education & 2 & 6,7 & 0 & 0,0 & 2 & 1,8 \\
No School & 17 & 56,7 & 27 & 33,7 & 44 & 40,0 \\
Elementaray School & 3 & 10,0 & 25 & 31,3 & 28 & 25,5 \\
Junior High School & 7 & 23,3 & 22 & 27,5 & 29 & 26,3 \\
Senior High School & 1 & 3,3 & 6 & 7,5 & 7 & 6,4 \\
Bachelor Degree & 30 & 100,0 & 80 & 100,0 & 110 & 100,0 \\
Total & & & & & & \\
Occupation & 20 & 66,7 & 51 & 63,7 & 71 & 64,6 \\
Housewife & 6 & 20,0 & 9 & 11,3 & 15 & 13,7 \\
Farmers & 0 & 0 & 2 & 2,5 & 2 & 1,8 \\
Fisherman & 3 & 10,0 & 12 & 15,0 & 15 & 13,6 \\
General employees & 1 & 3,3 & 6 & 7,5 & 7 & 6,3 \\
Civil Servant & 30 & 100,0 & 80 & 100,0 & 110 & 100,0 \\
Total & & & & & & \\
Familiy Involvement & 25 & 83,3 & 65 & 81,3 & 90 & 81,8 \\
No & 5 & 16,7 & 15 & 18,7 & 20 & 18,2 \\
Yes & 30 & 100,0 & 80 & 100,0 & 110 & 100,0 \\
\hline Total & & & & & & \\
\hline
\end{tabular}

Source: Primary Data.

Table 2. Social Determinants Effect of Health Risk Factors To the incidence of maternal mortality In Central Sulawesi Province.

\begin{tabular}{lllllll}
\hline \multirow{2}{*}{ Social Determinant of Health } & Case & & Control & & Total & \multicolumn{1}{c}{$\boldsymbol{C I ~ 9 5 \%}$} \\
\cline { 2 - 7 } & $\mathbf{n}$ & $\mathbf{\%}$ & $\mathbf{N}$ & $\mathbf{\%}$ & $\mathbf{n}$ & $\mathbf{\%}$ \\
\hline Risky & 19 & 63,3 & 27 & 33,7 & 46 & 41,8 \\
No Risk & 11 & 36,7 & 53 & 66,3 & $64=3,776$ & 58,2 \\
\hline
\end{tabular}

Source: Primary Data.

Table 3. Characteristics of Respondents based on Delay Factors (3 Delays) in Central Sulawesi Province.

\begin{tabular}{|c|c|c|c|c|c|c|}
\hline Variable & Case & & Control & & Tota & \\
\hline Delays & $\mathbf{n}$ & $\%$ & $\mathbf{n}$ & $\%$ & $\mathbf{n}$ & $\%$ \\
\hline \multicolumn{7}{|c|}{ Delays of decision making } \\
\hline Delay ( $>24$ Hour) & 5 & 16,7 & 11 & 13,7 & 16 & 14,5 \\
\hline Emergency $(<24$ jam $)$ & 25 & 83,3 & 69 & 86,3 & 94 & 85,5 \\
\hline
\end{tabular}




\begin{tabular}{|c|c|c|c|c|c|c|}
\hline Variable & Case & & Control & & Tot & \\
\hline Delays & $\mathbf{n}$ & $\%$ & $\mathbf{n}$ & $\%$ & $\mathbf{n}$ & $\%$ \\
\hline \multicolumn{7}{|c|}{ Delays arrived at the health facility } \\
\hline Delays (> 2 Hour) & 10 & 33,3 & 18 & 22,5 & 28 & 25,4 \\
\hline Fast $(<=2$ Hour $)$ & 20 & 66,7 & 62 & 77,5 & 82 & 74,6 \\
\hline \multicolumn{7}{|c|}{ Delays of treatment at a health facility } \\
\hline Delays ( $>=30$ minute) & 12 & 40,0 & 9 & 11,3 & 21 & 19,1 \\
\hline Fast $(<30$ minute $)$ & 18 & 60,0 & 71 & 88,7 & 89 & 80,9 \\
\hline
\end{tabular}

Source: Primary Data.

Table 4. The Effect of Delay Risk Factors (3 Delays) To the incidence of maternal mortality in Central Sulawesi Province.

\begin{tabular}{|c|c|c|c|c|c|c|c|}
\hline \multirow{2}{*}{3 Delays } & \multicolumn{2}{|c|}{ Case } & \multicolumn{2}{|c|}{ Control } & \multicolumn{2}{|c|}{ Total } & \multirow{2}{*}{$\begin{array}{l}C l 95 \% \\
(L L-U L)\end{array}$} \\
\hline & $\mathrm{n}$ & $\%$ & $\mathbf{n}$ & $\%$ & $\mathbf{n}$ & $\%$ & \\
\hline \multicolumn{8}{|c|}{ DELAYS OF DECISION MAKING } \\
\hline Risky & 5 & 16,7 & 11 & 13,7 & 16 & 14,5 & $O R=1,680$ \\
\hline No Risk & 25 & 83,3 & 69 & 86,3 & 94 & 85,5 & $(0,553-5,100)$ \\
\hline \multicolumn{8}{|c|}{ DELAYS OF ARRIVED AT HEALTH FACILITY } \\
\hline Risky & 10 & 33,3 & 18 & 22,5 & 28 & 25,4 & $O R=2,038$ \\
\hline No Risk & 20 & 66,7 & 62 & 77,5 & 82 & 74,6 & $(0,820-5,064)$ \\
\hline \multicolumn{8}{|c|}{ DELAYS OF TREATMENT AT HEALTH FACILITY } \\
\hline Risky & 12 & 40,0 & 9 & 11,3 & 21 & 19,1 & $O R=6,500$ \\
\hline No Risk & 18 & 60,0 & 71 & 88,7 & 89 & 80,9 & $(2,342-18,044)$ \\
\hline
\end{tabular}

Sourcer: Primary Data.

\section{Discussion}

Indonesia has diversity in habits, ceremony, culture and norms that apply in the community, especially those related to maternal and child health. Many factors affect it, especially socio-cultural factors in the community. Perspective which considers that pregnancy is a natural process and has become the nature of women is inherent in most pregnant women. This makes them feel unnecessary to check their pregnancy and cause the detection of high risk factors that can cause difficulties at the time of delivery and fatality this can result in death. Even if there is an emergency that requires the mother to be referred to a health facility, often the decision is too late because the authority is still in the hands of the head of the family (husband). [6, 7]

This condition can be seen from the results of research on the contribution of social determinants to the incidence of maternal mortality in Central Sulawesi. There were $83.3 \%$ of cases of maternal / maternal mortality caused by noninvolvement of mothers in the decision making process. This delay will affect the delay in providing assistance in health facilities. Besides the delay factor in the decision making process, there is also the contribution of the education factor as a social determinant. As many as $63.3 \%$ of respondents in the case group were mothers with a low level of education (elementary school equivalent).

The results of the bivariate analysis showed an $\mathrm{OR}$ value $=$ 3.776 at $95 \%$ CI. This shows that when Social Determinants of Health do not play a role, then 3,776 times the risk of causing maternal / maternal deaths than if social determinants of health play a role. And this is a significant / strong factor towards maternal mortality in Central Sulawesi.

The results showed that the case of maternal mortality in Central Sulawesi was largely caused by the delay in the hospital providing medical assistance $(40 \%)$, followed by the delay in the first-level health facility (Community Health Center) referring cases (33.3\%). Both of these delays occur often because they are preceded by the delay of the mother and family in making a decision to be referred. The results showed that the delay of the family in making decisions to be referred which contributed to the incidence of maternal / maternal mortality by $16.7 \%$. However, when looking at the involvement of mothers in the decision-making process independently is quite low $(16.7 \%)$. The family, especially the husband, is the party most involved in decision making. [4, 8]

The results of the bivariate analysis showed that the OR value (at 95\% CI) at the late $1=1,680$, at the late $2=2,038$ and at the late $3=6,500$. This means that the delay of the mother / family in making a decision to be referred to health services is 1,680 times the risk of causing a maternal / maternal mortality than that of a pregnant woman / family who is not late in making a decision to be referred immediately; delay of pregnant women / families arriving at health facilities (due to transportation constraints) at 2,038 times the risk of causing maternal / maternal deaths compared to pregnant women who are not late arriving at health facilities; as well as delays in pregnant women getting medical treatment at a health facility (Community Health Center/Hospital) at a risk of 6,500 times causing the death of pregnant / childbirth women compared to pregnant / childbirth women who get medical treatment immediately. The results also found that among the 3 late, 1 late and 2 late were not significant factors in the incidence of maternal mortality in Central Sulawesi. While being late 3 is a significant factor in the incidence of maternal mortality in Central Sulawesi. Crosssectoral collaboration needs to be continued in order to significantly reduce maternal mortality, especially interventions on social determinants $[9,10]$.

Research facts show that in the area of maternal mortality there are still many pregnant women who have guarantees from national health insurance but deliver at home and assisted 
by traditional healers. this Proves that high costs are not a reason for delivery in a health facility. Especially in areas where maternal mortality is high, there are still many pregnant women who take the trial and error that is to give birth at home and are helped by a shaman, and if there is a problem, then call the midwife, if the midwife is unable to repair, then it is taken to health facility or referred to hospital. There is hope from pregnant women and families not to give birth in the hospital, because giving birth in a health facility or hospital is perceived as a maternity mother in a protected condition. $[10,11]$

The importance of early detection of high risk of pregnancy since $\mathrm{ANC}$, so that risk factors that have the potential to bring the mother to an emergency can be anticipated early. Hospitals further enhance preparedness in emergency management of comprehensive emergency neonatal obstetric services. $[12,13]$

The advantage of this research is to discuss in more detail about the social determinant variables. Issues of family culture and education level that have an impact on the model of care for pregnancy, childbirth and the puerperium, have turned out to be a cause of obstetric complications in pregnant and childbirth women. Likewise in efforts to achieve antenatal care, family planning and utilization of health facilities, cultural and educational factors are key issues [14-16]. On the other hand, the poverty factor that was born from the low level of family income and the effect of the work of pregnant women as a consequence of the absence of gender equality, has encouraged pregnant women to undergo pregnancy and childbirth as they are and tend to be trapped in traditional rituals that are very far from efforts to maintain healthy and safe pregnancy and childbirth. The weakness of this study is the study has not discussed qualitatively the causes of maternal mortality in Palu City and Parigi Moutong District.

\section{Conclusion}

Social Determinant of Health has a risk of 3,776 times increasing maternal mortality $(\mathrm{OR}=3,776)$ and is a significant factor in maternal mortality in Central Sulawesi (1,579-9,301).

Delays (3 Late) acts as a risk factor for maternal death in Central Sulawesi, namely: 1 Late risk 1,680 times increases maternal mortality $(\mathrm{OR}=1,680)$ but is not a significant factor in maternal mortality in Central Sulawesi (0.553$5,100)$; Being late 2 is at risk of 2,038 times increasing maternal mortality $(\mathrm{OR}=2,038)$ but is not a significant factor in maternal mortality in Central Sulawesi (0.8205.064); and being Late 3 at a risk of 6,500 times increasing maternal mortality $(\mathrm{OR}=6,500)$ and is a significant factor in maternal mortality in Central Sulawesi $(2,342-18,044)$.

\section{Acknowledgements}

The author would like to thank all those who helped in this research process, especially the Head of Health Departement in Palu City and Parigi Moutong District.

\section{References}

[1] Amiruddin R \& Hasni. Determinan Kesehatan Ibu dan Anak. CV. Trans Info Media; 2014. 13-17 p.

[2] Alkema Leontine et. all. Global, regional, and national levels and trends in maternal mortality between 1990 and 2015, with scenario-based projections to 2030: a systematic analysis by the UN Maternal Mortality Estimation Inter-Agency GroupNo Title. Lancet. 2016; 387 (10017).

[3] WHO. World Health Statistics, Monitoring Health For SDGs. 2018.

[4] Khoeroh H. Evaluasi Program Perencanaan Persalinan dan Pencegahan Komplikasi (P4K) Sebagai Upaya Menurunkan A1. Khoeroh H. Evaluasi Program Perencanaan Persalinan dan Pencegahan Komplikasi (P4K) Sebagai Upaya Menurunkan Angka Kematian Ibu di Puskesmas Paguyangan Kab. J Kesehat Ilm Indones (Indonesian Heal Sci J. 2018; 4 (2): 37-40.

[5] Suparmi et. all. Hubungan Kepemilikan Buku KIA Terhadap Peningkatan Pemanfaatan Pelayanan Kesehatan Maternal Di Indonesia. 2019; 9 (2): 159-66.

[6] Hidayati. Analisis Implementasi Program Perencanaan Program Persalinan dan Pencegahan Komplikasi Dengan Stiker Dalam Menyiapkan Calon Pendonor Darah Siap Pakai Oleh Bidan Desa Di Kabupaten Pekalongan. Indones J Heal Sci. 2018; 2 (2): 115-28.

[7] Handayani S \& Mubarokah K. Kondisi Demografi Ibu Dan Suami Pada Kasus Kematian Ibu. Higeia J Public Heal. 2019; 3 (1): 99-108.

[8] Ahmalia R \& Parmisze A. Hubungan Pengetahuan, Pendidikan dan Dukungan Suami Dengan Kunjungan Pemeriksaan Antenatal Care di Puskesmas Lubuk Alung Tahun 2017. J Hum Care. 2018; 3 (1): 12-20.

[9] Widodo Y. Pengaruh faktor sosial ekonomi dan budaya terhadap perilaku persalinan di perdesaan daerah Angka kematian ibu rendah dan tinggi. J Kesehat Reproduksi. 2017; 8 (1): 77-88.

[10] Nisa K, et. all. Analisis Faktor yang Berhubungan dengan Kinerja Bidan dalam Memberikan Pelayanan Antenatal Berkualitas Diwilayah Kerja Puskesmas Kota Bukittinggi Tahun 2018. 2019; 19 (1): 53-60.

[11] Nurmawati \& Indrawati F. Cakupan Kunjungan Antenatal Care Pada Ibu Hamil. Higeia J Public Heal. 2018; 2 (1): 11324.

[12] Aborigo RA, et. all. Male Involvement In Maternal Health: Perspectives Of Opinion Leaders. BMC Pregnancy Childbirth. 2018; 18 (3): 1-10.

[13] Azizah I \& Oktiaworo K. Kematian Neonatal Di Kabupaten Grobogan. Higeia J Public Heal. 2017; 1 (4): 72-85.

[14] Sari K. I. P \& Veny V. E. Analisis Faktor Yang Berpengaruh Terhadap Kunjungan Antenatal Care. J Keperawatan dan Kebidanan. 2017; 9 (1): 93-113.

[15] Lestari M. Faktor Kejadian Anemia Pada Ibu Hamil. Higeia J Public Heal. 2017; 1 (3): 43-54. 